\title{
PENGARUH PROPAGASI MADDEN JULIAN OSCILLATION (MJO) DI BENUA MARITIM INDONESIA (BMI) TERHADAP SIKLUS DIURNAL DINAMIKA ATMOSFER DAN CURAH HUJAN DI PROVINSI LAMPUNG TAHUN 2018
}

\author{
The Influence of Madden Julian Oscillation (MJO) Propagation over \\ Indonesian Maritime Continent (IMC) on the Diurnal Cycle of Atmospheric \\ Dynamics and Rainfall in Lampung Province in 2018
}

\author{
Sindy Maharani'), Hasti Amrih Rejeki²) \\ 1)Stasiun Meteorologi Kelas I I Gusti Ngurah Rai. Denpasar, Indonesia \\ ${ }^{2}$ Sekolah Tinggi Meteorologi Klimatologi dan Geofisika. Tangerang Selatan, Indonesia \\ *e-mail: sindymaharani55@gmail.com
}

\begin{abstract}
Intisari
Madden Julian Oscillation (MJO) merupakan osilasi gelombang submusiman di wilayah tropis yang berpropagasi ke arah timur dari Samudera Hindia melewati Benua Maritim Indonesia (BMI) hingga Samudera Pasifik. Propagasi MJO dapat meningkatkan konvektivitas dan curah hujan pada wilayah yang dilewatinya. Lampung merupakan salah satu wilayah di BMI bagian barat yang berbatasan dengan Samudera Hindia sebagai tempat awal kemunculan MJO. Posisi Lampung tersebut menyebabkan perbedaan insolasi antara daratan dan lautan secara diurnal sehingga siklus diurnal ikut berperan dalam pembentukan cuaca. Oleh karena itu penelitian ini bertujuan untuk mengetahui pengaruh propagasi MJO dari Fase 3-5 pada tahun 2018 terhadap siklus diurnal dinamika atmosfer dan curah hujan di Lampung. Siklus diurnal dianalisis dengan membagi empat periode waktu yaitu dini hari (00.00-06.00 LT), pagi hari (06.00-12.00 LT), siang hari (12.00-18.00 LT) dan malam hari (18.00-00.00 LT). Berdasarkan rata-rata komposit data Reanalysis ECMWF, GSMaP, dan curah hujan observasi didapatkan bahwa selama penjalarannya MJO menguat ketika Fase 3-4 dan melemah ketika Fase 5. Secara diurnal konvektivitas yang kuat dan curah hujan tinggi terjadi di perairan pada dini hari hingga pagi hari, di daerah pesisir pada siang hari, dan di daratan pada malam hari yang meningkat dari Fase 3-4 dan melemah pada Fase 5. Hujan menjalar dari Lampung bagian barat menuju Lampung bagian tengah dengan jeda waktu selama 2-5 jam ketika Fase 3, 47 jam ketika Fase 4, dan 1-2 jam ketika Fase 5. Pada Fase 3-5 hujan terjadi di Lampung bagian timur dengan perbedaan waktu 1-3 jam dari Lampung bagian tengah.
\end{abstract}

Kata kunci: MJO, Siklus Diurnal, Konvektif, Curah Hujan, Propagasi

\begin{abstract}
Madden Julian oscillation (MJO) is a sub-seasonal wave oscillation in the tropics that propagates eastward from the Indian Ocean through the Indonesian Maritime Continent (IMC) until the Pacific Ocean. MJO propagation can increase convective and rainfall in the regions it passes. Lampung is one of the regions in the western IMC which near the Indian Ocean for the MJO first appeared. The Lampung position causes different insolation between land and sea diurnally, so the diurnal cycles play an important role in weather formation. Therefore, this study aims to determine the effect of MJO propagation phases 3-5 in 2018 on the diurnal cycle of atmospheric dynamics and rainfall in Lampung. The diurnal cycle was analyzed by dividing four periods of time, in the early morning (00$06 L T)$, morning (06-12 LT), afternoon (12-18 LT), and night (18-00 $L T)$. Based on the average composite of ECMWF, GSMaP, and precipitation observations data were obtained that propagation MJO strengthens during phase 3-4 and weakens during phase 5. Diurnal strong convective and high rainfall occur in the oceans from early morning to morning, in coastal during the day, and on land at night which increases from phase 3-4 and weakens in phase 5. Rain propagates from western Lampung to central Lampung with a time lag of 2-5 hours during phase 3, 4-7 hours when phases 4, and $1-2$ hours during phase 5. In the 3-5 phase, rain occurs in eastern Lampung with a time difference of 1-3 hours from central Lampung.
\end{abstract}

Keywords: MJO, Diurnal Cycle, Convective, Rainfall, Propagation 


\section{PENDAHULUAN}

Madden Julian Oscillation (MJO) merupakan suatu gelombang atau osilasi submusiman dengan periode 30-60 hari yang terjadi di lapisan troposfer wilayah tropis, dan bergerak dari barat ke timur yaitu dari Samudera Hindia menuju Samudera Pasifik Tengah dengan rentang daerah penjalaran $15^{\circ} \mathrm{LU}-15^{\circ} \mathrm{LS}$ (Madden dan Julian, 1971;1972;1994). MJO bergerak mengelilingi bumi dari arah barat ke timur melewati 8 fase, Fase 1 dimulai dari wilayah Afrika dekat Samudera Hindia dan terus merambat ke arah timur menuju Fase 8 di wilayah Samudera Pasifik bagian timur (Higgins dan Shi, 2001). Pada saat MJO aktif akan terlihat peningkatan aktivitas konvektif dan berdampak besar terhadap sebagian besar cuaca di wilayah tropis yang dilewatinya (Madden dan Julian 1994). Hal tersebut membuat MJO menjadi sumber utama adanya variabilitas curah hujan submusiman di daerah tropis (Zhang et al., 2009).
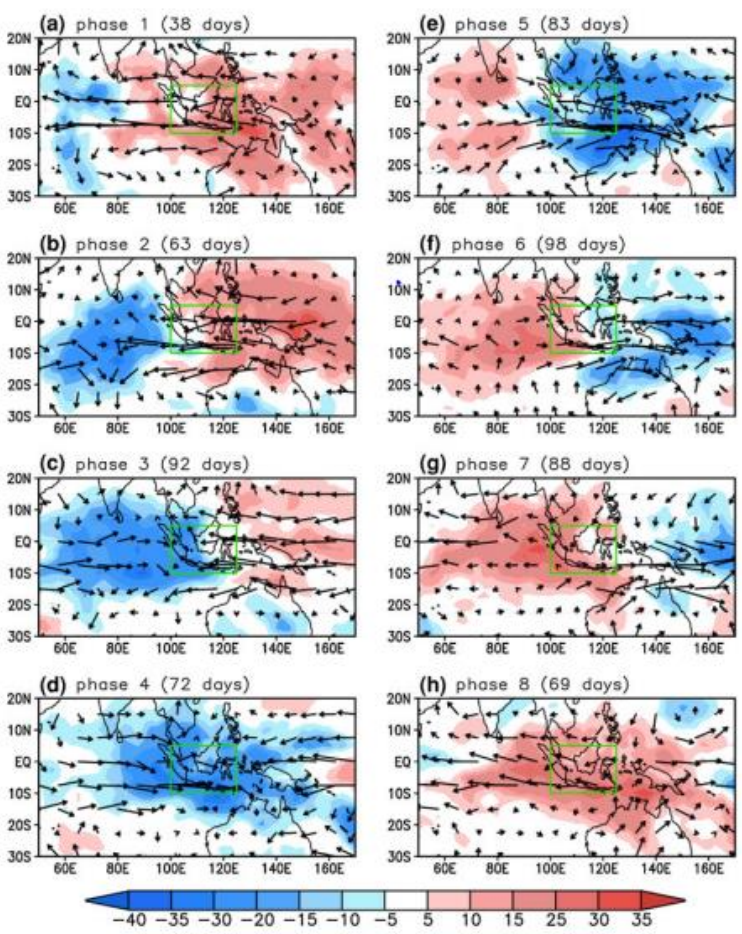

Gambar 1. Komposit OLR dan anomali angin $850 \mathrm{mb}$ setiap fase MJO (Oh et al., 2011)

Benua Maritim Indonesia (BMI) merupakan salah satu wilayah tropis yang termasuk kedalam daerah penjalaran MJO pada Fase 3 hingga Fase 5 (Gambar 1), sehingga kondisi cuaca di BMI dipengaruhi oleh adanya penjalaran MJO yang pembentukannya berada di Samudera Hindia (Hidayat dan Kizu, 2009). Selain itu, posisi BMI tersebut menyebabkan proses cuaca yang terjadi di BMI memiliki siklus diurnal yang menonjol dengan perbedaan aktivitas konvektif yang signifikan antara wilayah daratan dan lautan (Oh et al., 2011). Perbedaan insolasi (incoming solar radiation) pada siang hari dan malam hari membentuk perbedaan suhu antara daratan dan lautan, akibatnya pada siang hari aktivitas konvektif terjadi di atas daratan, sedangkan pada malam hari aktifitas konvektif terjadi di atas lautan (Lu dan Wang, 2019). Perbedaan insolasi tersebut menunjukkan adanya siklus diurnal yang kuat di BMI (Nesbitt dan Zipser, 2003). MJO dapat menjadi sumber utama adanya variasi siklus diurnal kondisi atmosfer sebagai proses konvektivitas dan curah hujan di BMI (Peatman et al., 2014).

Beberapa penelitian mengenai pengaruh propagasi MJO terhadap siklus diurnal di wilayah BMI telah dilakukan oleh Oh et al. (2011), Peatman et al. (2014), dan Lu dan Wang (2019) yang hasilnya menunjukan selama propagasi MJO siklus diurnal curah hujan meningkat selama Fase 2-5 dan berkurang selama Fase 6-8. Menurut Oh et al. (2011) konvergensi yang intens dan upward yang kuat dominan terjadi di daratan pada malam hari dan di lautan pada tengah malam hingga pagi hari. Hal tersebut yang memicu curah hujan tinggi di lautan pukul 00-08 LT dan pertama kali muncul di pesisir pada sore hari hingga malam hari (14-20 LT) kemudian maksimum di daratan pukul 20-00 LT. Peningkatan curah hujan ditandai dengan adanya konvergensi dan kelembaban yang tinggi hingga lapisan atas sehingga meningkatkan aktivitas konvektif. Penelitian serupa untuk wilayah yang lebih sempit di BMI telah dilakukan di Kototabang oleh Syafrijon (2013) yang hasilnya menunjukan bahwa ketika MJO aktif terjadi peningkatan jumlah curah hujan dengan kejadian hujan lebih dominan terjadi pada sore hingga malam hari dan berlangsung selama 7 jam. Selain itu, Arbain et al., (2017) melakukan penelitian siklus diurnal selama MJO aktif di Jakarta yang menunjukkan distribusi hujan bergerak dari Selatan ke Utara pada siang hari.

Salah satu wilayah BMI lainnya yang mendapatkan pengaruh terhadap penjalaran MJO adalah Lampung. Hal ini dikarenakan Lampung terletak pada koordinat $3^{\circ} 45^{\prime}-6^{\circ} 45^{\prime}$ LS dan $105^{\circ} 45^{\prime}-103^{\circ} 48^{\prime}$ BT yang berbatasan langsung dengan Samudera Hindia. Samudera Hindia merupakan daerah awal pembentukan MJO yang kemudian berpropagasi dari barat menuju timur, sehingga wilayah Lampung dilewati oleh lintasan MJO pada setiap siklusnya (Hermawan, 2010). Ketika fase penjalaran MJO sudah mulai memasuki dan mempengaruhi wilayah Lampung akan menyebabkan aktivitas konvektif meningkat (Hermawan, 2011). Hal tersebut akan memicu pembentukan awan-awan konvektif yang cukup banyak dengan skala besar yang dikenal Super Cloud Clusters (SCCs) dan dapat mempengaruhi kondisi atmosfer dan curah hujan di wilayah BMI bagian barat khususnya Lampung (Hermawan, 2010). Wilayah Lampung yang memiliki daerah pesisir pantai menyebabkan proses pembentukan cuaca di Lampung tidak terlepas dari adanya perbedaan daratan dan lautan pada siang dan 
malam hari, yang artinya siklus diurnal ikut berperan dalam pembentukan cuaca di wilayah Lampung (Wirjohamidjojo dan Swarinoto, 2010).

Berdasarkan penelitian-penelitian yang telah dilakukan sebelumnya (Hidayat dan Kizu, 2009; Hermawan, 2010), maka diperlukan penelitian mengenai pengaruh propagasi MJO terhadap kondisi atmosfer dan curah hujan di wilayah Lampung yang merupakan salah satu wilayah terdekat dengan Samudera Hindia sebagai daerah awal pembentukan MJO. Oleh karena itu diperlukan penelitian yang mengkaji bagaimana propagasi MJO dan pengaruhnya terhadap kondisi atmosfer dan curah hujan di Lampung saat MJO aktif dari Fase 3 hingga Fase 5 secara diurnal sehingga dapat dijadikan sebagai bahan acuan dalam prediksi hujan dan peringatan dini di wilayah Lampung.

\section{DATA DAN METODE}

\subsection{Data}

Data indeks RMM1 dan RMM2 dalam bentuk diagram Fase MJO digunakan untuk identifikasi MJO aktif dari Fase 3-5 diperoleh dari Bureau of Meteorology Australia. Data curah hujan observasi setiap jam selama tahun 2018 yang digunakan untuk melihat siklus diurnal curah hujan ketika MJO aktif Fase 3-5 diperoleh dari Automatic Weather Station (AWS) dan Automatic Rain Gauge (ARG) di Lampung. Data curah hujan setiap jam dari Global Satellite Mapping of Precipitation (GSMaP) dengan resolusi spasial $0.1^{0} \times 0.1^{0}$ selama tahun 2018 digunakan untuk melihat propagasi dan distribusi curah hujan secara spasial selama MJO aktif Fase 3-5. Data reanalysis ERA5 European Centre for MediumRange Weather Forecast (ECMWF) digunakan untuk melihat kondisi dinamika atmosfer sebagai aktivitas konvektif ketika MJO aktif Fase 3-5. Data ECMWF yang diunduh merupakan data divergensi, kecepatan vertikal, dan kelembaban relatif $(\mathrm{RH})$ harian dengan resolusi temporal per jam selama tahun 2018 untuk lapisan 850 mb dan $500 \mathrm{mb}$ dengan resolusi spasial $0,125^{\circ} \times 0,125^{\circ}$.

\subsection{Metode}

Identifikasi kejadian MJO dilakukan dengan mengelompokkan tanggal kejadian MJO aktif Fase 3-5 dari data RMM1 dan RMM2. Tanggaltanggal kejadian MJO aktif yang telah diidentifikasi akan dijumlahkan hari kejadian MJO aktif untuk masing-masing fase MJO. Jumlah hari kejadian MJO aktif ini akan digunakan dalam mengolah data selanjutnya dengan mengkompositkan data sesuai dengan jumlah hari kejadian MJO aktif setiap fasenya.

Selanjutnya membuat peta rata-rata komposit data GSMaP dan ECMWF secara global $\left(15^{\circ} \mathrm{LU}-15^{\circ} \mathrm{LS}\right.$ dan $\left.40^{\circ} \mathrm{BT}-160^{\circ} \mathrm{BB}\right)$ dan di Lampung $\left(7^{0}-3^{\circ} \mathrm{LS}\right.$ dan $\left.97-110^{\circ} \mathrm{BT}\right)$ selama MJO aktif Fase 3-5 sehingga dapat diketahui penjalaran MJO. Selain itu data diolah dengan membuat peta rata-rata komposit akumulasi curah hujan setiap 6 jam dari GSMaP dan rata-rata komposit dinamika atmosfer dari ECMWF setiap 6 jam, yaitu dini hari (00.00-06.00 LT), pagi hari (06.00-12.00 LT), siang hari (12.00-18.00 LT) dan malam hari (18.00-00.00 LT). Data curah hujan AWS dan ARG akan dibuat grafik frekuensi kejadian hujan per jam untuk setiap fase.

Tabel 1. Jumlah Kejadian MJO Setiap fase

\begin{tabular}{|c|c|}
\hline Fase MJO & Jumlah hari kejadian MJO \\
\hline Fase 3 & 35 \\
\hline Fase 4 & 23 \\
\hline Fase 5 & 37 \\
\hline Total kejadian & 95 \\
\hline
\end{tabular}

\section{HASIL DAN PEMBAHASAN}

\subsection{Propagasi MJO Fase 3-5 di BMI}

Berdasarkan hasil penelitian menunjukkan adanya aktivitas konvektif yang menjalar ke arah timur selama MJO aktif. Gambar 3 menunjukkan ketika Fase 3 (Gambar 3 (a)) terjadi konvergensi pada lapisan $850 \mathrm{mb}$ dengan gerakan massa udara (upward) yang kuat pada lapisan 500 mb mulai memasuki Benua Maritim Indonesia (BMI) namun meluas hingga BMI bagian timur. Memasuki Fase 4 (Gambar 3 (b)) area konvektivitas bergeser ke timur yaitu di BMI bagian tengah hingga timur BMI dengan nilai yang semakin meningkat. Pada Fase 5 (Gambar 3 (c)) area konvektivitas semakin bergeser ke arah timur hingga Samudera Pasifik bagian barat dengan nilai yang semakin kecil dari fase-fase sebelumnya.

Selaras dengan area konvektif, nilai $\mathrm{RH}$ pada lapisan 850 dan 500 mb ketika Fase 3 (Gambar 4 (a) dan (b)) berkisar antara 70-85\%. Pada lapisan $850 \mathrm{mb}$ dan sekitar $65-85 \%$ pada lapisan $500 \mathrm{mb}$. Penjalaran MJO terlihat jelas pada lapisan $500 \mathrm{mb}$. Wilayah dengan $\mathrm{RH}$ tinggi meluas dari BMI bagian barat hingga BMI bagian timur ketika Fase 4 (Gambar 4 (c) dan (d)). Memasuki Fase 5 (Gambar 4 (e) dan (f)) $\mathrm{RH}$ tertinggi semakin bergeser ke arah timur sehingga nilai $\mathrm{RH}$ di wilayah BMI bagian barat mulai berkurang sedangkan nilai $\mathrm{RH}$ di wilayah BM bagian timur lebih tinggi daripada $\mathrm{RH}$ di BMI bagian barat.

Wilayah konvektif dengan $\mathrm{RH}$ yang tinggi berpengaruh terhadap penjalaran hujan ketika MJO. Berdasarkan Gambar 5(a) ketika Fase 3 curah hujan tinggi bernilai antara 20-50 mm meluas dari Samudera Hindia hingga Samudera Pasifik bagian barat dengan wilayah curah hujan tertinggi sesuai dengan wilayah fase aktifnya yaitu berada di Samudera Hindia bagian timur yang mencapai $50 \mathrm{~mm}$ dan mulai memasuki BMI bagian barat. 


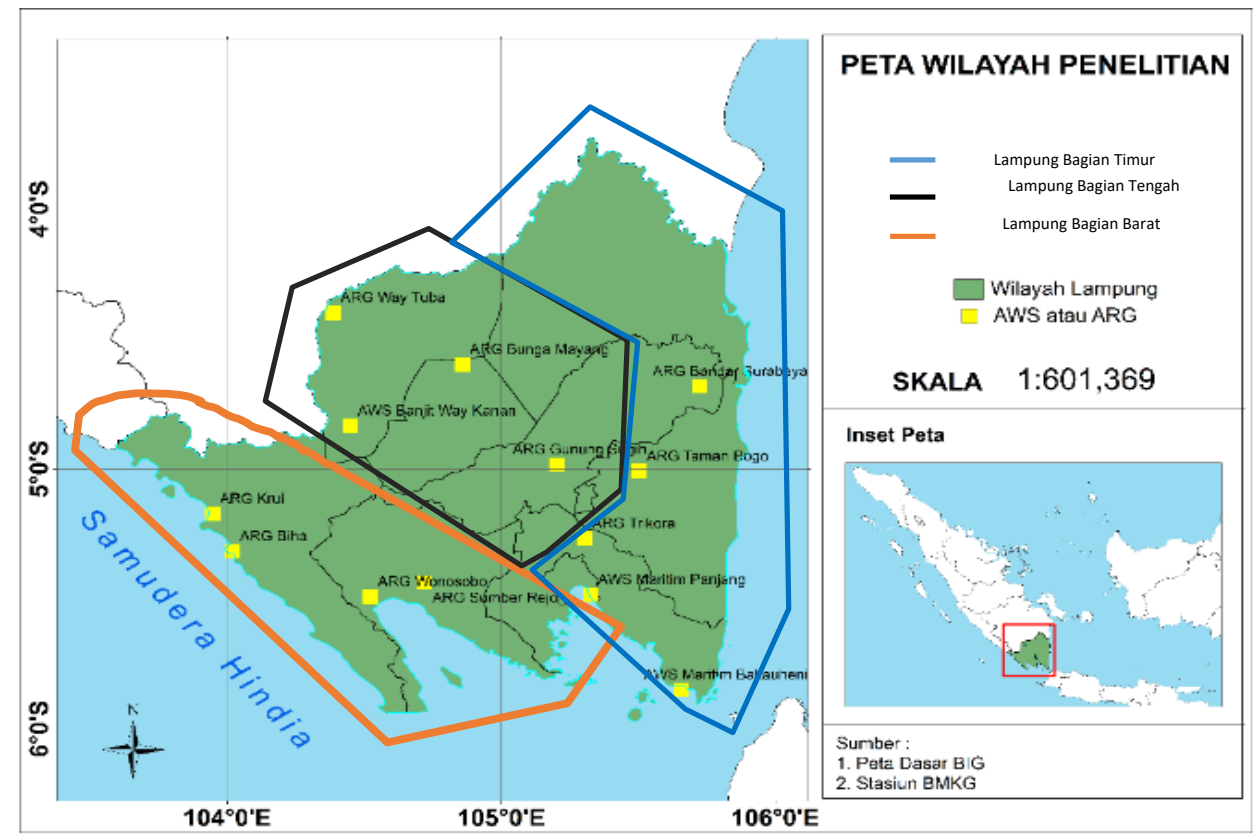

Gambar 2. Peta penelitian

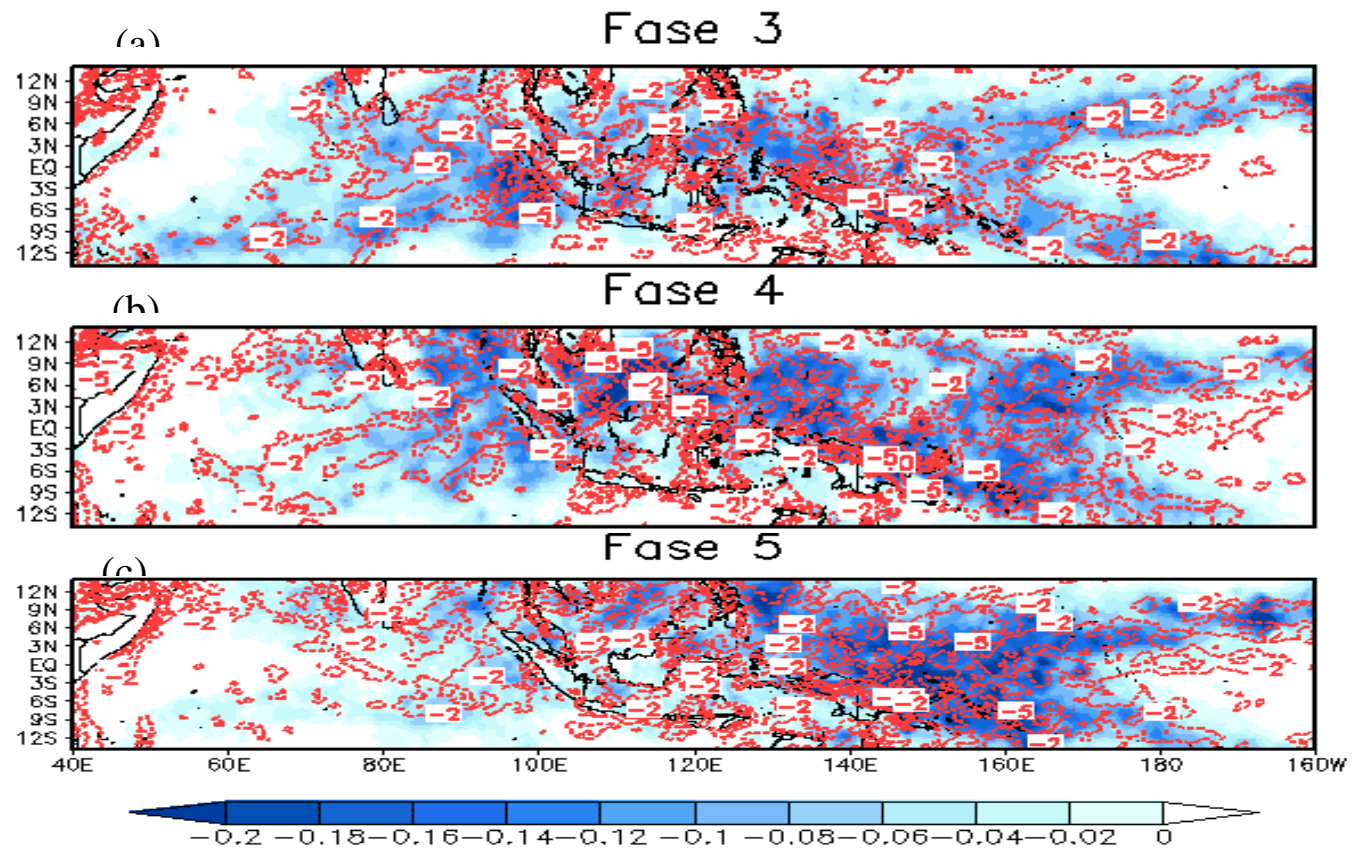

Gambar 3. Penjalaran divergensi lapisan $850 \mathrm{mb}$ (contour, $\times 10^{-6} \mathrm{~s}^{-1}$ ) dan kecepatan vertikal lapisan $500 \mathrm{mb}$ (shaded, $\mathrm{Pa} \mathrm{s}^{-1}$ ) ketika MJO a) Fase 3, b) Fase 4, c) Fase 5 
(a)

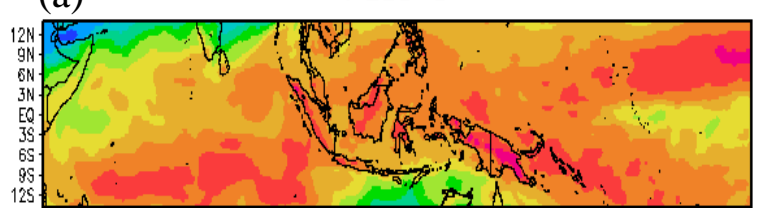

(c)

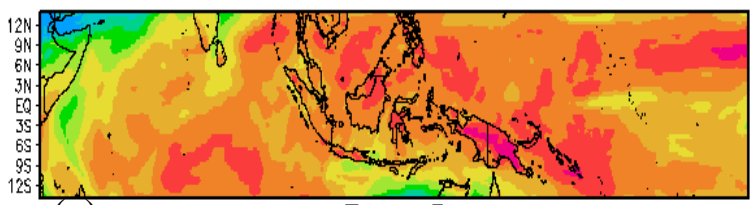

(e)

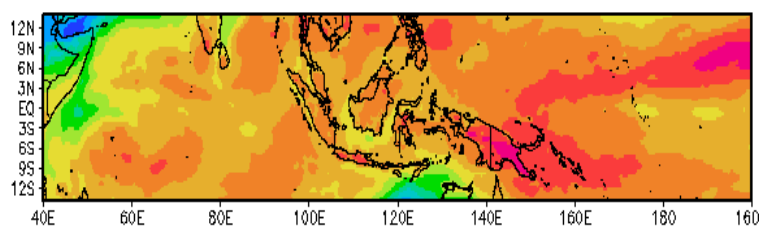

(b)

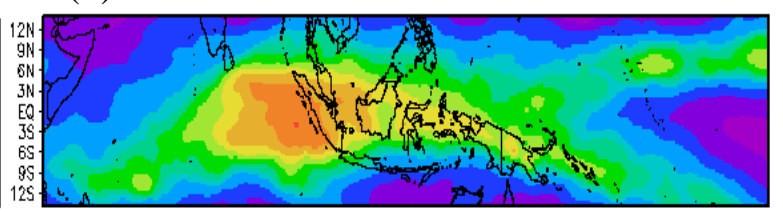

(d)

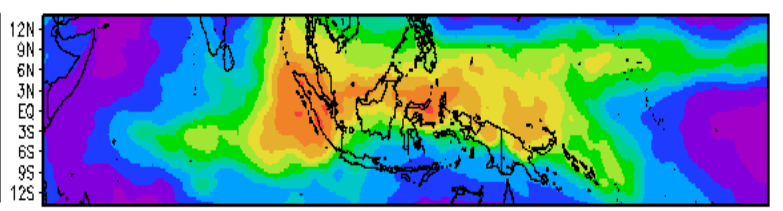

(f)

Fase 5

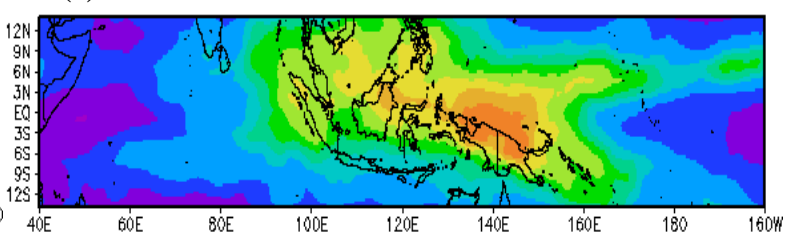

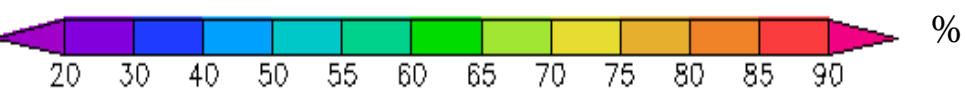

Gambar 4. Penjalaran kelembaban relative $(\mathrm{RH})$ lapisan $850 \mathrm{mb}(\mathrm{a}-\mathrm{c})$ dan lapisan $500 \mathrm{mb}(\mathrm{d}-\mathrm{f})$

Fase 3

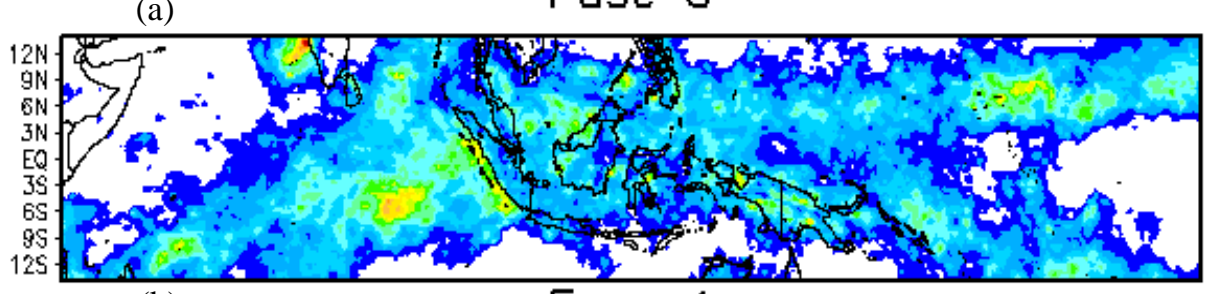

(b)

Fase 4

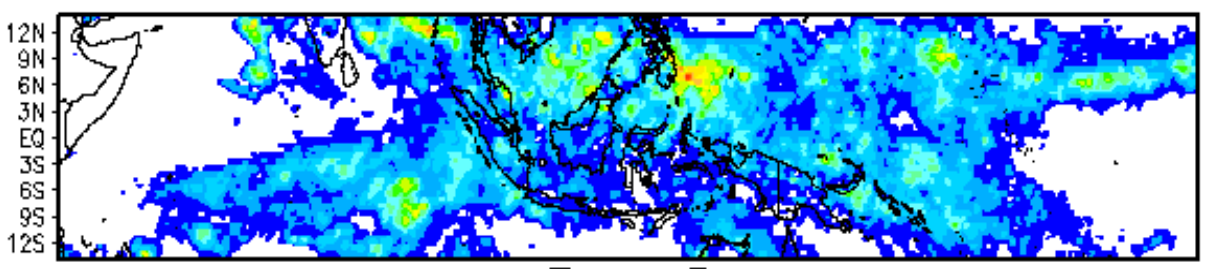

(c)

Fase 5

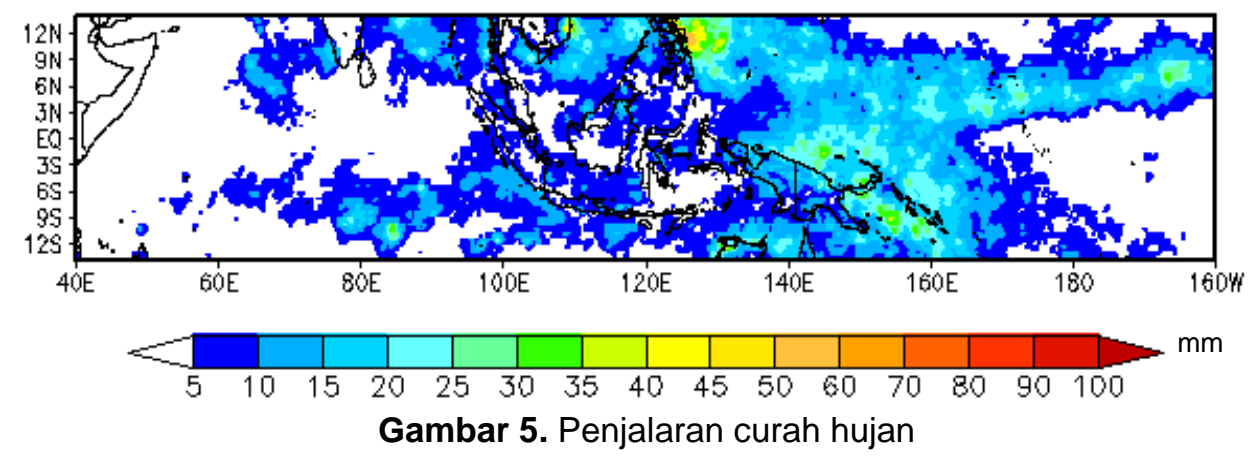

Ketika Fase 4 (Gambar 5 (b)) curah hujan di wilayah Samudera Hindia bagian timur dan BMI bagian barat semakin berkurang, sedangkan di BMI bagian timur hingga Samudera Pasifik lebih tinggi. Memasuki Fase 5 (Gambar 5 (c)) wilayah dengan curah hujan tinggi sesuai dengan wilayah fase aktifnya yaitu semakin bergeser ke arah timur dari fase sebelumnya dan semakin meluas hingga
Samudera Pasifik bagian barat dengan intensitas curah hujan yang semakin menurun.

Terlihat adanya aktivitas konvektif yang menjalar ke arah timur selama MJO aktif. Selama penjalaran $\mathrm{MJO}$, konvektif meningkat dari Fase 3 hingga Fase 4 dan mulai melemah ketika MJO aktif di wilayah BMI bagian timur yaitu pada Fase 5. Hal tersebut hampir serupa dengan penelitian Zhang dan Ling (2017) yang menyatakan bahwa 
MJO sangat kuat ketika memasuki BMI dan mulai melemah ketika berada di atas BMI. Menurut Wu dan Hsu (2009) ketika MJO memasuki BMI maka penjalaran MJO akan terhambat dan melemah karena faktor topografi. Hal tersebut menyebabkan penjalaran MJO semakin melemah bahkan menghilang ketika memasuki Samudera Pasifik. Pelemahan MJO di atas BMI tersebut dikenal sebagai efek barrier (Wu dan Hsu, 2009).

\subsection{Siklus Diurnal Dinamika Atmosfer di Lampung Ketika MJO Fase 3-5}

Berdasarkan Gambar 6 ketika pukul 00-06 LT (Gambar 6 (a-c)) wilayah konvergensi dengan kecepatan vertikal tertinggi berada di wilayah perairan barat Lampung. Kecepatan vertikal dengan nilai tertinggi terjadi ketika Fase 3 dan Fase 4 (Gambar 6 (a) dan (b)) mencapai -0.2 Pa $\mathrm{S}^{-1}$ dengan konvergensi bernilai sebesar $-4 \times 10^{-6}$ $\mathrm{s}^{-1}$ hingga $-10 \times 10^{-6} \mathrm{~s}^{-1}$ di perairan barat Lampung. Memasuki Fase 5 (Gambar 6 (c)) kecepatan vertikal di perairan barat Lampung mulai berkurang menjadi $-0.12 \mathrm{~Pa} \mathrm{~S}^{-1}$ dengan wilayah konvergensi yang semakin kecil.

Pukul 06-12 LT (Gambar 6 (d-e)) wilayah konvergensi masih dominan terjadi di wilayah perairan barat Lampung dan mulai tinggi di wilayah pesisir barat Lampung sebesar $-10 \times 10^{-6}$ $\mathrm{s}^{-1}$, namun kecepatan vertikal menjadi lebih rendah daripada kecepatan vertikal pukul 00-06 LT. Ketika Fase 3 dan Fase 4 (Gambar 6 (d) dan (e)) kecepatan vertikal paling tinggi mencapai -0.2 $\mathrm{Pa} \mathrm{S}^{-1}$ di perairan barat Lampung hingga pesisir barat Lampung. Kecepatan vertikal dan konvergensi mulai berkurang ketika memasuki Fase 5 (Gambar 6 (f)) baik di wilayah perairan maupun daratan.

Wilayah konvergensi dengan kecepatan vertikal yang tinggi meluas dari perairan barat Lampung hingga daratan pada pukul 12-18 LT (Gambar 6 (g-i)). Kecepatan vertikal tinggi lebih merata di wilayah daratan daripada wilayah perairan. Kecepatan vertikal tertinggi terjadi ketika Fase 3 dan Fase 4 (Gambar 6 (g) dan (h)) yang mencapai -0.2 $\mathrm{Pa} \mathrm{S}^{-1}$ di wilayah daratan dengan nilai konvergensi mencapai $-12 \times 10^{-6} \mathrm{~s}^{-1}$. Pada Fase 5 (Gambar 6 (i)) konvergensi semakin kecil dan kecepatan vertikal di wilayah daratan semakin berkurang menjadi $-0.12 \mathrm{~Pa} \mathrm{~S}^{-1}$.

Pada pukul 18-00 LT (Gambar 6 (j-I)) wilayah konvergensi dengan kecepatan vertikal tinggi masih dominan terjadi di perairan hingga daratan Lampung bagian barat dan tinggi di pesisir barat Lampung. Kecepatan vertikal paling tinggi terjadi ketika Fase 3 dan Fase 4 (Gambar 6 (j) dan (k)) mencapai $-0.2 \mathrm{~Pa} \mathrm{~S}^{-1}$ di perairan barat Lampung hingga daratan Lampung bagian tengah. Memasuki Fase 5 (Gambar 6 (I)) nilai kecepatan vertikal menjadi lebih kecil dan wilayah konvergensi semakin berkurang di wilayah daratan dan pesisir barat Lampung.

Berdasarkan Gambar 7 yang merupakan $\mathrm{RH}$ pada lapisan $850 \mathrm{mb}$ secara diurnal di
Lampung, $\mathrm{RH}$ meningkat dari Fase 3 hingga Fase 4 dan kemudian menurun pada Fase 5 . $\mathrm{RH}$ lapisan 850 mb pada pukul 00-06 LT (Gambar 7 (a-c)) tertinggi berada di perairan barat Lampung hingga Lampung bagian barat. Pada Fase 3 (Gambar 7 (a)) $\mathrm{RH}$ bernilai 85\% di perairan barat Lampung hingga daratan. Fase 4 dan 5 (Gambar 7 (b) dan (c)) $\mathrm{RH}$ semakin berkurang setiap fasenya.

Pukul 06-12 LT (Gambar 7 (d-f)) RH semakin meningkat dari sebelumnya. Ketika Fase 3 (Gambar 7 (c)) $\mathrm{RH}$ mencapai 85\% di wilayah perairan barat Lampung. Memasuki Fase 4 (Gambar 7 (d)) RH tertinggi semakin meluas ke timur hingga pesisir Lampung mencapai 85\%. Memasuki Fase 5 (Gambar 7 (e)) $\mathrm{RH}$ semakin berkurang menjadi 75-80 \% dan merupakan $\mathrm{RH}$ yang paling rendah jika dibandingkan dengan Fase 3 dan Fase 4.

$\mathrm{RH}$ tertinggi lapisan $850 \mathrm{mb}$ pada pukul 1218 LT (Gambar 7 (g-i)) berada di pesisir barat Lampung hingga daratan Lampung bagian barat. $\mathrm{RH}$ pada Fase 3 (Gambar 7 (g)) tertinggi berada di pesisir barat Lampung hingga daratan Lampung bagian barat mencapai $85 \%$. $\mathrm{RH}$ tinggi dengan nilai $85 \%$ di pesisir barat Lampung semakin meluas hingga Lampung bagian timur pada Fase 4 (Gambar 7(h)). Fase 5 (Gambar 7 (i)) $\mathrm{RH}$ tertinggi berada di pesisir barat Lampung namun berkurang menjadi 75\%. Pada pukul 18-00 LT (Gambar $7(\mathrm{j}-\mathrm{l})$ ) tertinggi berada di daerah pesisir barat Lampung dan meluas hingga daratan Lampung. $\mathrm{RH}$ mencapai $85 \%$ di Lampung bagian timur ketika Fase 3 dan Fase 4 (Gambar 7 (j) dan (5)). Pada Fase 5 (Gambar 7 (I)) $\mathrm{RH}$ mulai menurun menjadi $80 \%$.

Berdasarkan Gambar 8 kondisi $\mathrm{RH}$ lapisan $500 \mathrm{mb}$ secara diurnal menunjukkan nilai $\mathrm{RH}$ tergolong tinggi meskipun nilainya lebih rendah daripada $\mathrm{RH}$ lapisan 850 mb. Secara diurnal tidak ada perbedaan yang signifikan pada $\mathrm{RH}$ pukul 0006LT hingga 18-00 LT (Gambar 8 (a-b), (d-f), (gi), dan (j-l)). Nilai $\mathrm{RH}$ tertinggi berada di perairan barat Lampung hingga Lampung bagian barat. $\mathrm{RH}$ tertinggi terjadi pada pukul 18-00 LT.

Ketika Fase 3 (Gambar 8 (a), (d), (g) dan (i)) $\mathrm{RH}$ bernilai $70-80 \%$ dengan $\mathrm{RH}$ tertinggi berada di wilayah perairan barat Lampung hingga Lampung bagian tengah, sedangkan Lampung bagian timur memiliki nilai $\mathrm{RH}$ yang lebih rendah. Nilai $\mathrm{RH}$ meningkat ketika Fase 4 (Gambar 8 (b), (e), (h), dan (j)) mencapai $85 \%$ di perairan barat Lampung. Pada Fase 5 (Gambar 8 (c), (f), (i) dan (I)) $\mathrm{RH}$ menjadi lebih rendah.

Gambar 9 merupakan kondisi diurnal curah hujan selama MJO Fase 3-5. Pada pukul 00-06 LT (Gambar 9 (a-c)) hujan intens terjadi di perairan barat Lampung dengan intensitas 3-14 $\mathrm{mm}$, sedangkan di daratan 0.1-6 mm. Curah hujan tinggi ketika Fase 3 (Gambar 9 (a)) mencapai 16 $\mathrm{mm}$ dan meluas ke selatan mencapai perairan barat Lampung. 
(a)
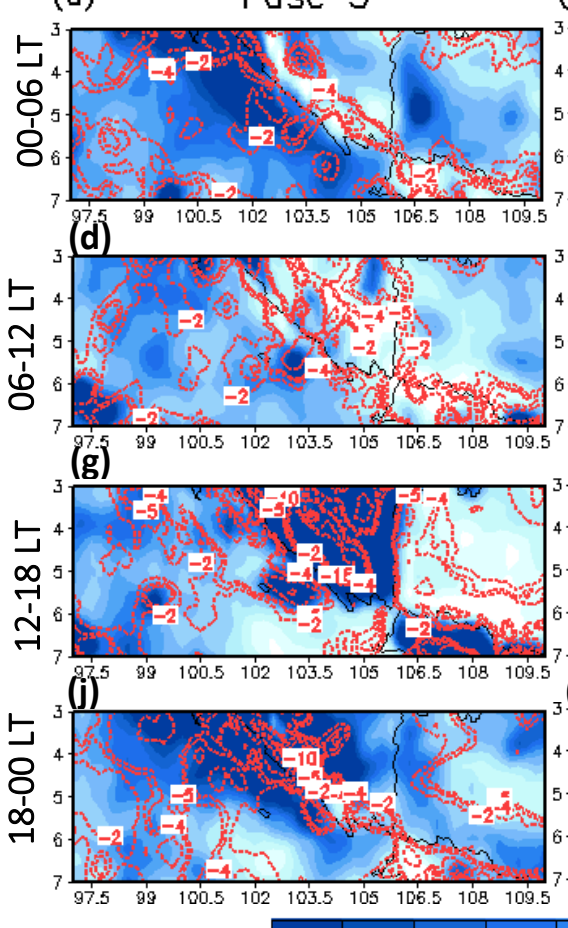

(b)
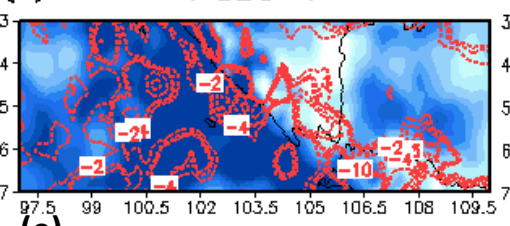
(e)

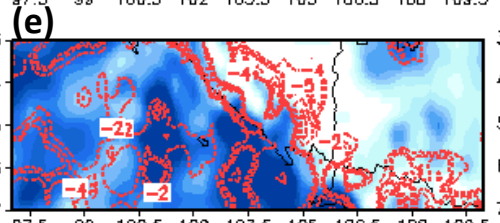
(h)
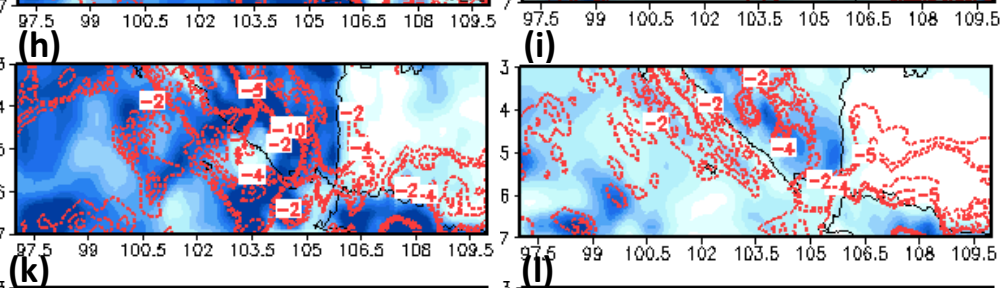

(c)

Fase 5
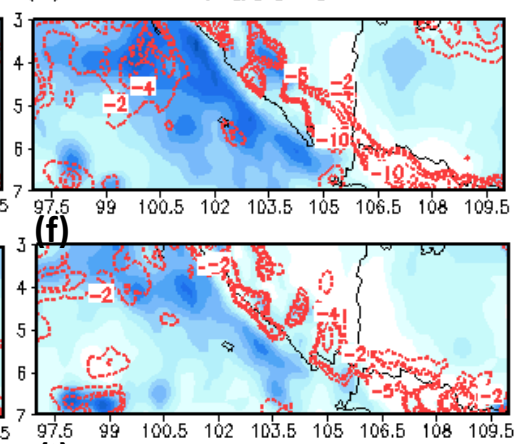
(i)

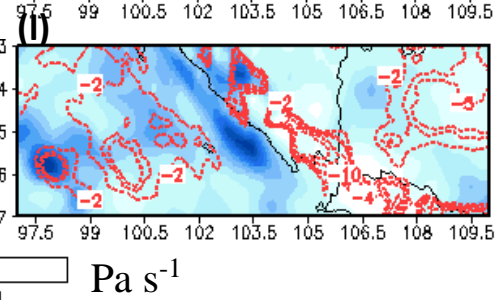

Gambar 6. Siklus diurnal divergensi lapisan $850 \mathrm{mb}$ (contour, $\times 10^{-6} \mathrm{~s}^{-1}$ ) dan kecepatan vertikal lapisan $500 \mathrm{mb}$ (shaded, Pa s${ }^{-1}$ ) ketika MJO a) Fase 3, b) Fase 4, c) Fase 5 pada pukul 00-06 LT; d, e, dan f pada pukul 06-12 LT; g, h, dan i pada pukul 12-18 LT; j, k, dan I pada pukul 18-00 LT.

Ketika Fase 4 (Gambar 9 (b)) curah hujan semakin meluas hingga perairan selatan Lampung, namun intensitas menurun menjadi 5-10 mm. Memasuki Fase 5 (Gambar 9 (c)) curah hujan di wilayah perairan barat Lampung semakin menurun menjadi 3-6 mm.

Kondisi curah hujan pada pukul 06-12 LT selama MJO aktif (Gambar 9 (d-f)) di Lampung masih tinggi di wilayah perairan, namun meluas di perairan barat Lampung, sedangkan di daratan mulai menurun. Hal ini menunjukkan hujan lebih intens terjadi di perairan daripada di daratan. Intensitas curah hujan di perairan barat Lampung berkisar antara 3-14 $\mathrm{mm}$, sedangkan di daratan 0.1-1 mm. Curah hujan ketika Fase 3 (Gambar 9 (d)) mencapai $12 \mathrm{~mm}$ merata di perairan barat Lampung. Pada Fase 4 (Gambar 9(e)) curah hujan tinggi semakin meluas hingga perairan selatan Lampung dengan intensitas 5-14 mm. Pada Fase 5 (Gambar 9 (f)) curah hujan menurun menjadi $3-6 \mathrm{~mm}$ di perairan barat dan selatan Lampung.

Curah hujan pada pukul 12-18 LT (Gambar $9(\mathrm{~g}-\mathrm{i}))$ masih tinggi di wilayah perairan terutama perairan barat Lampung. Pada pukul 12-18 LT curah hujan mulai memasuki wilayah daratan. Intensitas curah hujan di perairan barat Lampung hingga pesisir barat Lampung berkisar antara 4$14 \mathrm{~mm}$, sedangkan di daratan berkisar antara 1-7 $\mathrm{mm}$. Curah hujan tinggi ketika Fase 3 (Gambar7 (g)) mencapai $14 \mathrm{~mm}$ dan meluas di perairan barat Lampung hingga pesisir barat Lampung, selain itu curah hujan di daratan juga meningkat mencapai 3-9 mm. Ketika Fase 4 (Gambar 9 (h)) curah hujan di perairan barat Lampung mulai meningkat, namun curah hujan di daerah pesisir dan daratan menurun menjadi 3-7 mm. Kemudian memasuki Fase 5 (Gambar 9 (j)) curah hujan semakin menurun menjadi 1-3 mm di perairan barat Lampung dan pesisir barat Lampung dan 0.1-2 $\mathrm{mm}$ di daratan.

Curah hujan pada pukul 18-00 LT (Gambar $9(j-1))$ lebih rendah di perairan namun semakin tinggi di pesisir dan daratan. Hal ini menunjukkan bahwa pada pukul 18-00 LT terdapat pergeseran curah hujan tinggi ke arah timur. Intensitas curah hujan di perairan barat Lampung berkisar antara 3-6 $\mathrm{mm}$, sedangkan di daerah pesisir dan daratan mencapai 4-16 mm. Ketika Fase 3 (Gambar 9 (j)) curah hujan mencapai $16 \mathrm{~mm}$ dan meluas mencapai pesisir barat Lampung hingga daratan Lampung bagian timur. Ketika Fase 4 (Gambar 9 (k)) intensitas curah hujan berkurang namun semakin meluas di perairan barat Lampung, selain itu curah hujan di daerah pesisir dan daratan mulai menurun menjadi $3-10 \mathrm{~mm}$ dan meluas hingga pesisir timur Lampung. Ketika memasuki Fase 5 (Gambar 9 (I)) curah hujan menurun baik di pesisir dan di daratan menjadi 1$3 \mathrm{~mm}$. 

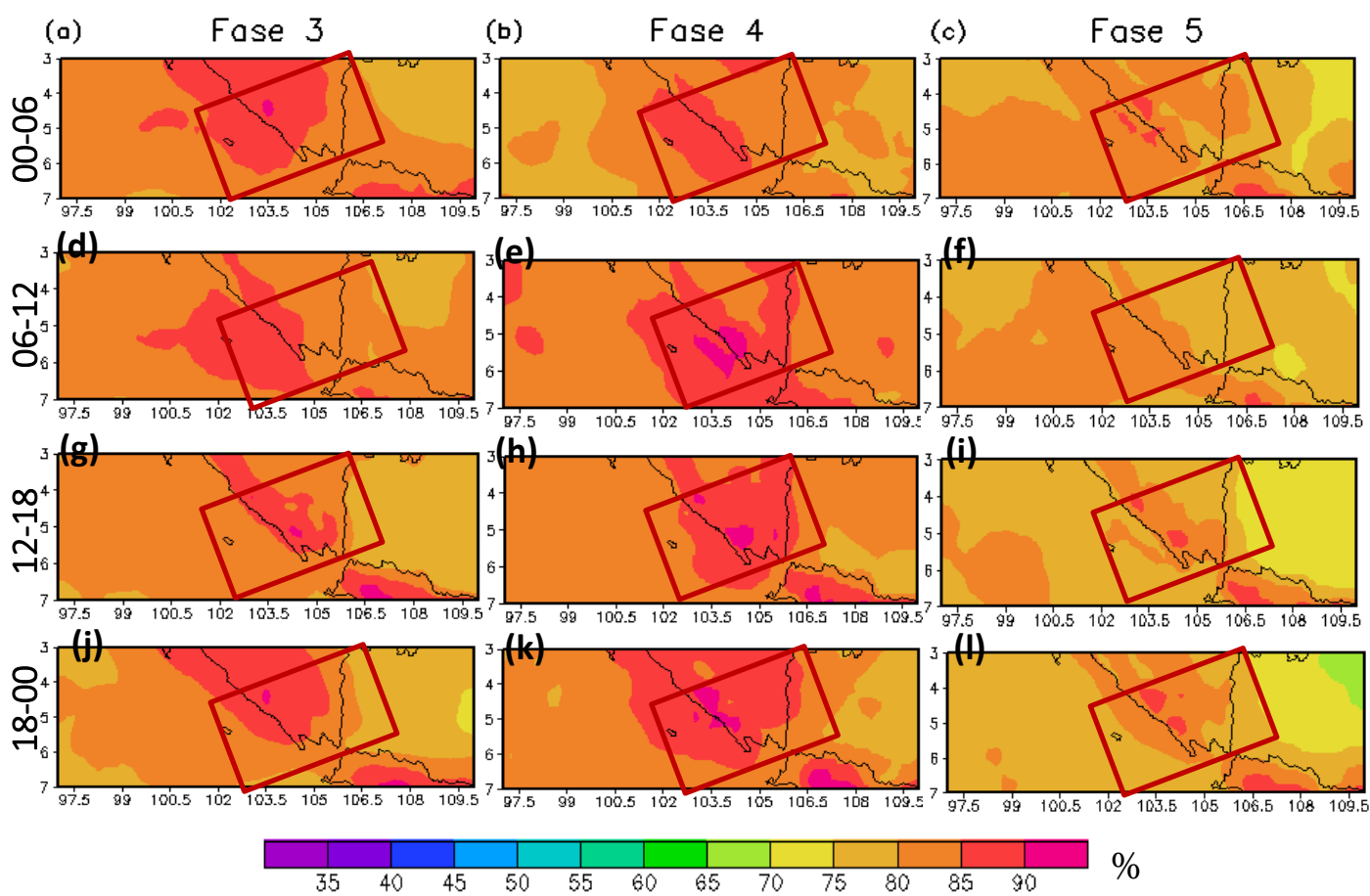

$\%$

Gambar 7. Kelembaban relatif (RH) lapisan $850 \mathrm{mb}$ diurnal ketika MJO a) Fase 3, b) Fase 4, c) Fase 5 pada pukul 00-06 LT; d, e, dan f pada pukul 06-12 LT; $g$, h, dan i pada pukul 12-18 LT; j, k, dan I pada pukul 18-00 LT.
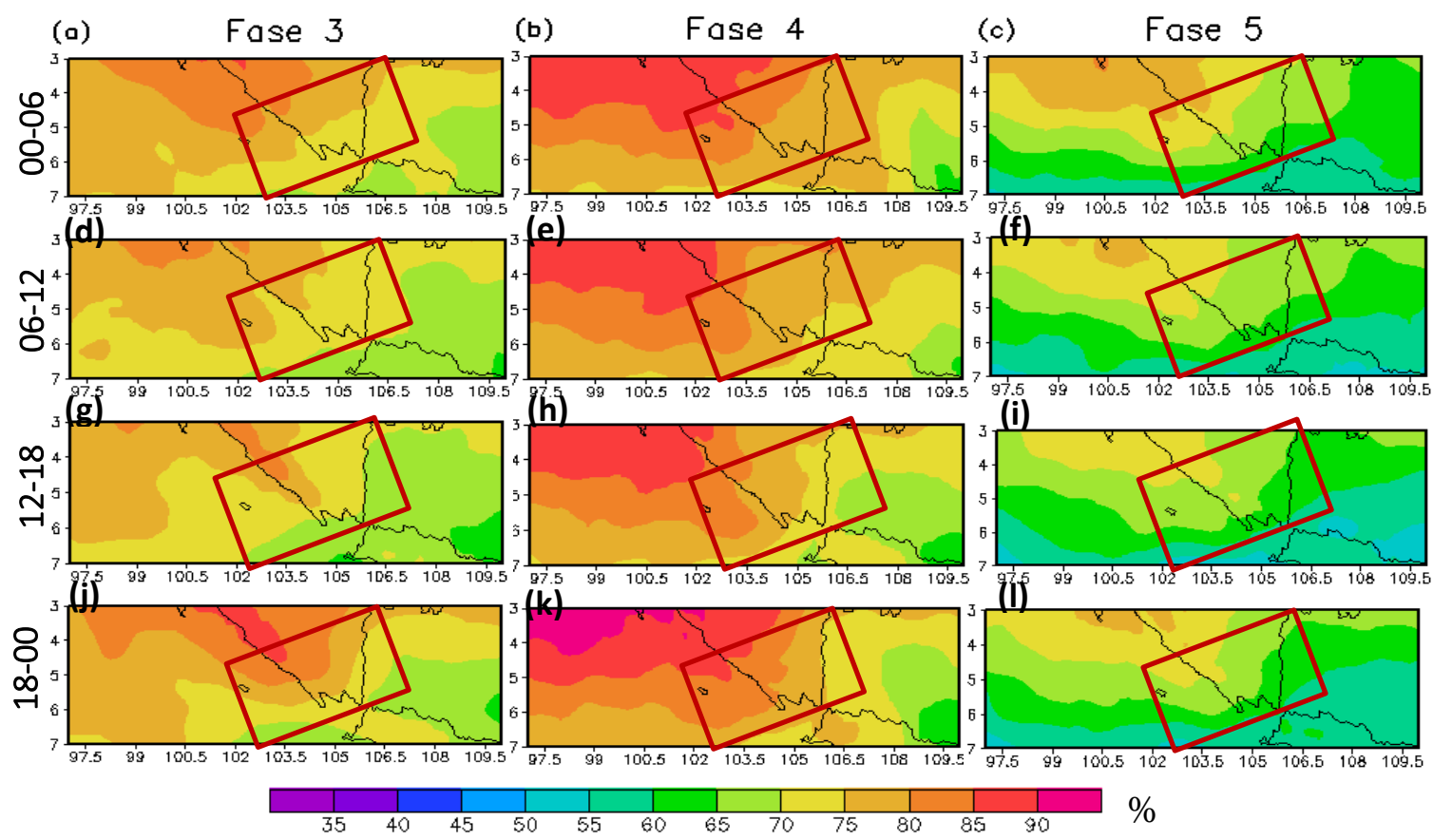

$\%$

Gambar 8. Kelembaban relatif (RH) lapisan $500 \mathrm{mb}$ diurnal ketika MJO a) Fase 3, b) Fase 4, c) Fase 5 pada pukul 00-06 LT; d, e, dan f pada pukul 06-12 LT; g, h, dan i pada pukul 12-18 LT; j, k, dan I pada pukul 18-00 LT. 
(a)
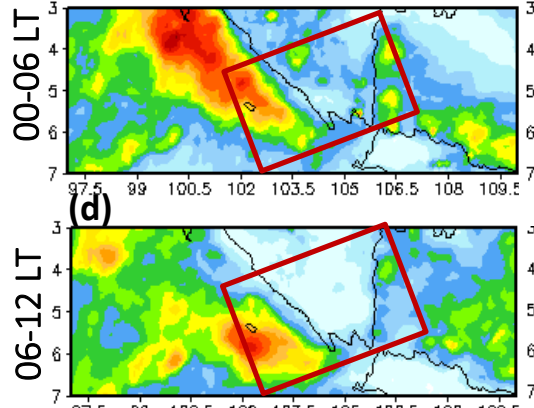

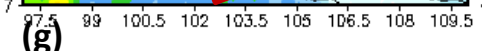
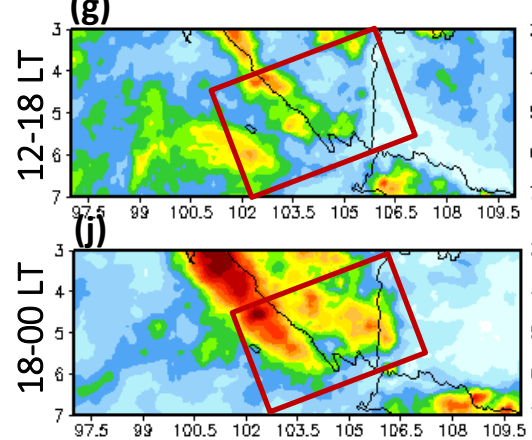

(b)

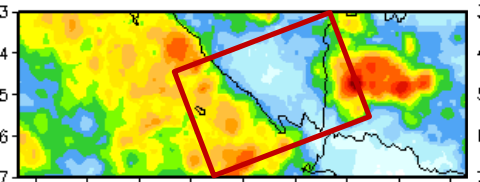

(e)

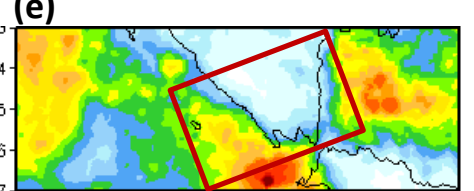

(h)

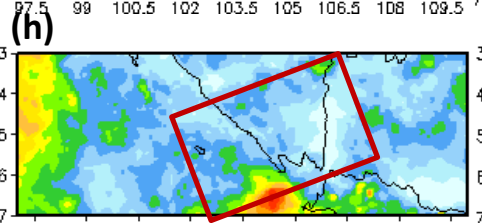

(k) (c) Fase 5

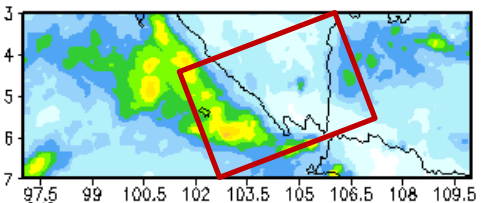

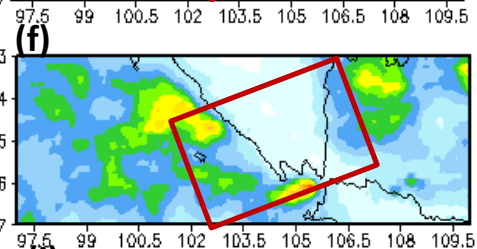
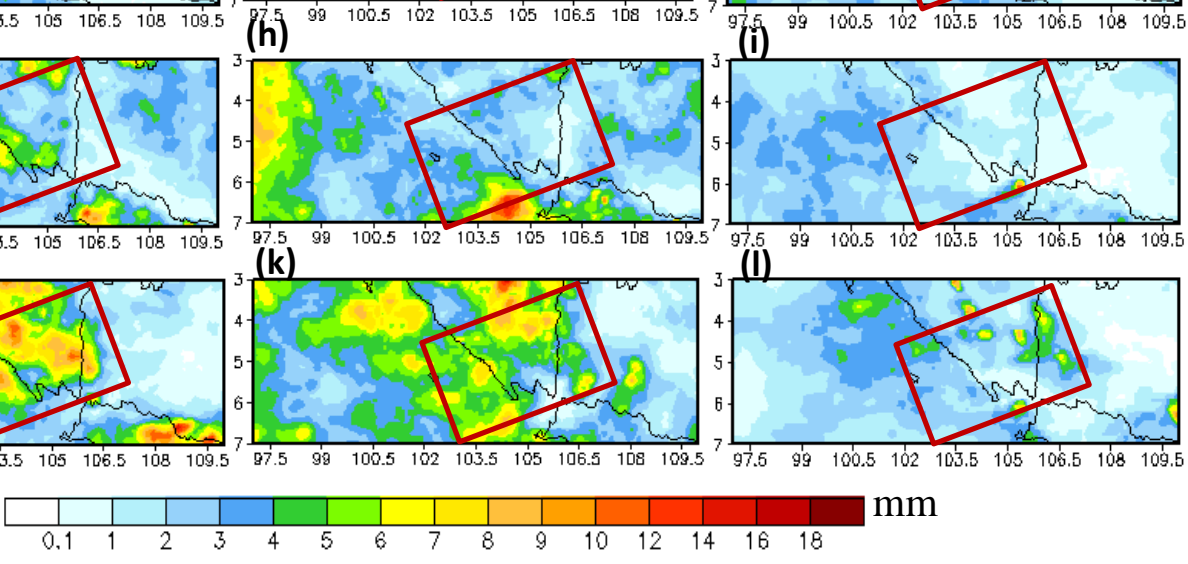

Gambar 9. Curah hujan diurnal ketika MJO a) Fase 3, b) Fase 4, c) Fase 5 pada pukul 00-06 LT; d, e, dan f pada pukul 06-12 LT; g, h, dan i pada pukul 12-18 LT; j, k, dan I pada pukul 18-00 LT.

Konvektivitas dan curah hujan diurnal mengalami peningkatan dari Fase 3 hingga Fase 4 kemudian menurun ketika Fase 5 . Menurut Lu dan Wang (2019) konvektivitas dan curah hujan diurnal pada BMI bagian barat meningkat pada tahap pembentukan MJO (Fase 1-4) karena anomali kelembaban pada lapisan atas bernilai positif di BMI bagian barat yang akan meningkatkan kandungan uap air untuk skala diurnal. Konvergensi diurnal pada Fase 1-4 juga lebih kuat karena menguatnya angin diurnal akibat penjalaran MJO ke timur. Siklus diurnal di Lampung melemah pada tahap matang (Fase 58).

Berdasarkan parameter divergensi, kecepatan vertikal, dan kelembaban relatif $(\mathrm{RH})$ menunjukkan bahwa adanya perbedaan konvektivitas yang jelas antara perairan dan daratan. Konvektivitas yang kuat terjadi di wilayah perairan pada malam hingga dini hari sedangkan di wilayah daratan pada siang hingga malam hari. Perbedaan konvektivitas antara daratan dan lautan tersebut dijelaskan oleh Wirjohamidjojo dan Swarinoto (2010) yang disebabkan karena adanya perbedaan sifat antara daratan dan lautan dalam menerima dan melepaskan panas matahari secara diurnal. Selain itu, menurut Peatman et al. (2014) adanya perbedaan temperatur antara daratan dan lautan pada siang hari menyebabkan adanya gradien tekanan antara daratan dan lautan sehingga memicu angin yang menjalar dari wilayah pesisir menuju daratan dan menyebabkan adanya penjalaran konvektivitas dan curah hujan dari pesisir menuju daratan secara diurnal.
Penjalaran curah hujan secara diurnal tersebut dapat dianalisis dengan menghitung akumulasi curah hujan 6 jam ARG dan AWS di Lampung (Gambar 10) sehingga dapat diketahui intensitas curah hujan dan waktu terjadinya di wilayah Lampung. Urutan ARG dan AWS dalam grafik dari kiri ke kanan dibuat berurutan sesuai dengan lokasi ARG dan AWS dari paling barat hingga paling timur. ARG paling kiri (Biha) merupakan ARG paling barat dari Lampung dan ARG paling kanan dalam grafik (Bandar Surabaya) merupakan ARG paling timur dari Lampung. Penjalaran hujan dari perairan barat Lampung menuju daratan Lampung bagian timur secara diurnal didukung oleh hasil penelitian curah hujan AWS dan ARG dimana intensitas curah hujan tertinggi terjadi pada pukul 12-18 LT di daerah pesisir barat Lampung dan semakin ke timur curah hujan tinggi terjadi ketika malam hari.

Pada Fase 3 dan Fase 4 (Gambar 10 (a) dan (b)) hujan intens terjadi pada semua waktu di ARG Biha dimana ARG Biha hingga ARG Banjit Way Kanan memiliki curah hujan tinggi ketika pukul 12-18 LT, sedangkan dari ARG Way Tuba hingga ARG Taman Bogo rata-rata curah hujan paling tinggi terjadi pada pukul 18-00 LT. Curah hujan tertinggi berkisar antara 2-8 $\mathrm{mm}$ pada Fase 3 dan 1-7 mm pada Fase 4. Pada Fase 5 (Gambar 10 (c)) curah hujan paling banyak terjadi di ARG Biha dan ARG Wonosobo dimana curah hujan tertinggi dari ARG Biha hingga ARG Bandar Surabaya terjadi ketika malam hari hingga dini hari dengan curah hujan 0.5-5 mm. 

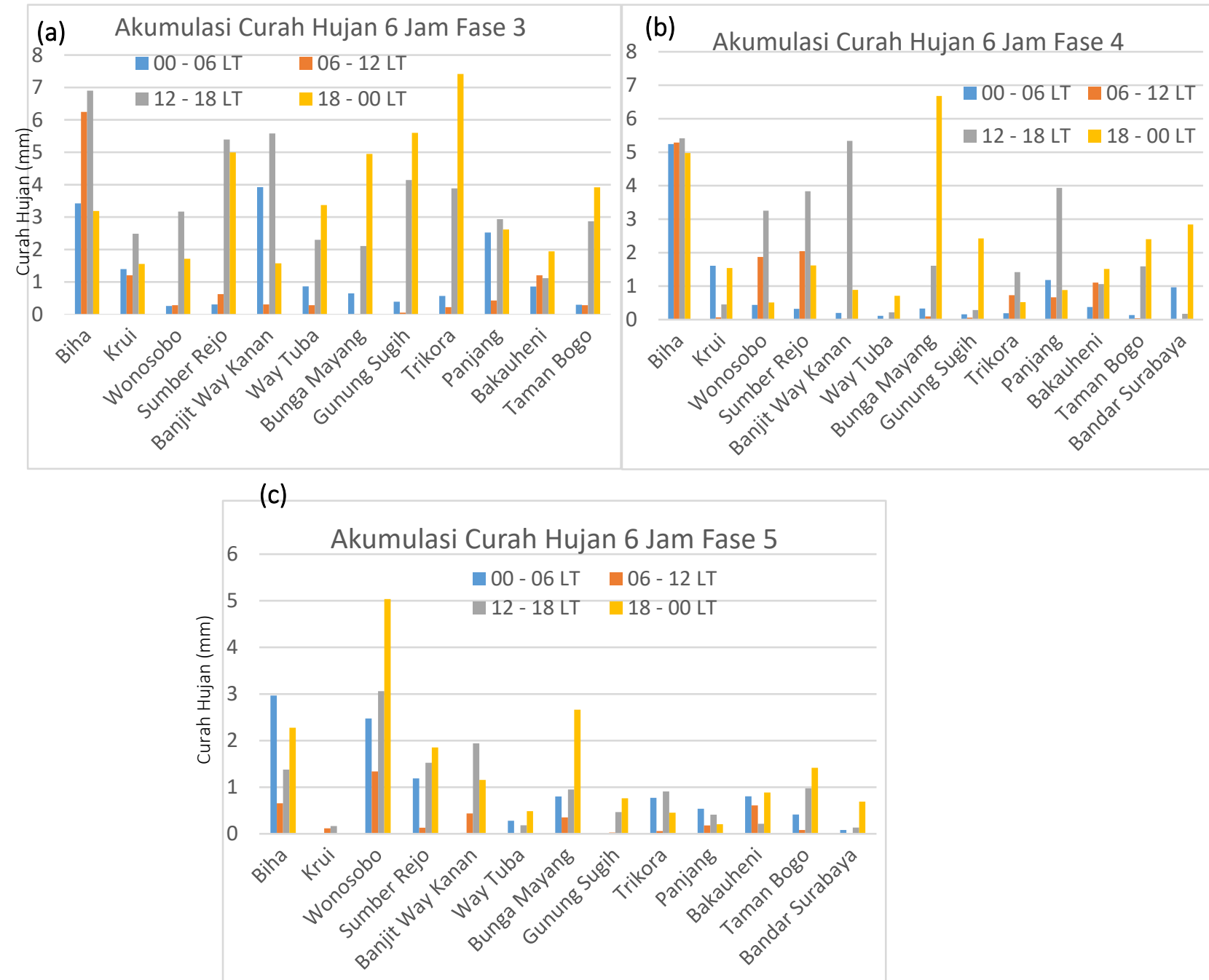

Gambar 10. Diagram rata-rata akumulasi curah hujan ARG dan AWS di Lampung per 6 jam pada a) Fase 3; b) Fase 4; dan c) Fase 5

Hasil analisis menunjukkan adanya penjalaran konvektivitas yang kuat ke arah timur dari perairan barat Lampung hingga daratan Lampung bagian timur. Penjalaran tersebut ditandai dengan konvergensi yang kuat pada lapisan $850 \mathrm{mb}$ disertai upward yang kuat hingga lapisan $500 \mathrm{mb}$ dari massa udara yang basah sehingga menyebabkan curah hujan yang tinggi di wilayah perairan pada pukul 00-06 LT dan 06-12 LT kemudian di daerah pesisir pada pukul 12-18 LT dan sampai di daratan pada pukul 18-00 LT. Hasil penelitian tersebut sesuai dengan penelitian yang dilakukan oleh Oh et al. (2011) yang menyatakan bahwa konvergensi dan upward yang kuat dominan terjadi di daratan pada malam hari dan di lautan pada tengah malam hingga pagi hari.

\subsection{Frekuensi Kejadian Hujan Ketika MJO Fase 3-5}

Pada Fase 3 (Gambar 11) di Lampung bagian barat (Gambar 11 (a)) hujan paling sering terjadi pada pukul 14-16 LT, kemudian di Lampung bagian tengah (Gambar 11 (b)) sering terjadi pukul 16-19 LT dan di Lampung bagian timur (Gambar 11 (c)) sering terjadi pukul 19-22 LT. Terdapat perbedaan waktu kejadian hujan selama 2-5 jam antara Lampung bagian barat dengan Lampung bagian tengah dan 5-7 jam antara Lampung bagian barat dengan Lampung bagian timur.

Pada Fase 4 (Gambar 12) hujan paling sering terjadi di Lampung bagian barat (Gambar 12 (a)) pada pukul 16-17 LT, kemudian di Lampung bagian tengah (Gambar 12 (b)) pukul 14-15 LT pada ARG gunung sugih dan 19-21 LT untuk ARG lainnya, sedangkan di wilayah Lampung bagian timur (Gambar 12 (c)) hujan paling sering terjadi pada pukul 20-23 LT. Terdapat perbedaan waktu kejadian hujan 5-7 jam antara Lampung bagian barat dengan timur.

Pada Fase 5 (Gambar 13) hujan paling sering terjadi hampir di semua waktu di Lampung bagian barat (Gambar $13($ a)) yaitu pada pukul 56 LT, 12-13 LT, dan 17-18 LT kemudian di Lampung bagian tengah (Gambar 13 (b)) hujan paling sering terjadi pada pukul 18-19 dan Lampung bagian timur (Gambar 13 (c)) pada pukul 19-21 LT. Terdapat perbedaan waktu kejadian hujan selama 1-2 jam antara Lampung bagian barat dengan Lampung bagian tengah dan 2-4 jam antara Lampung bagian barat dengan Lampung bagian timur. 


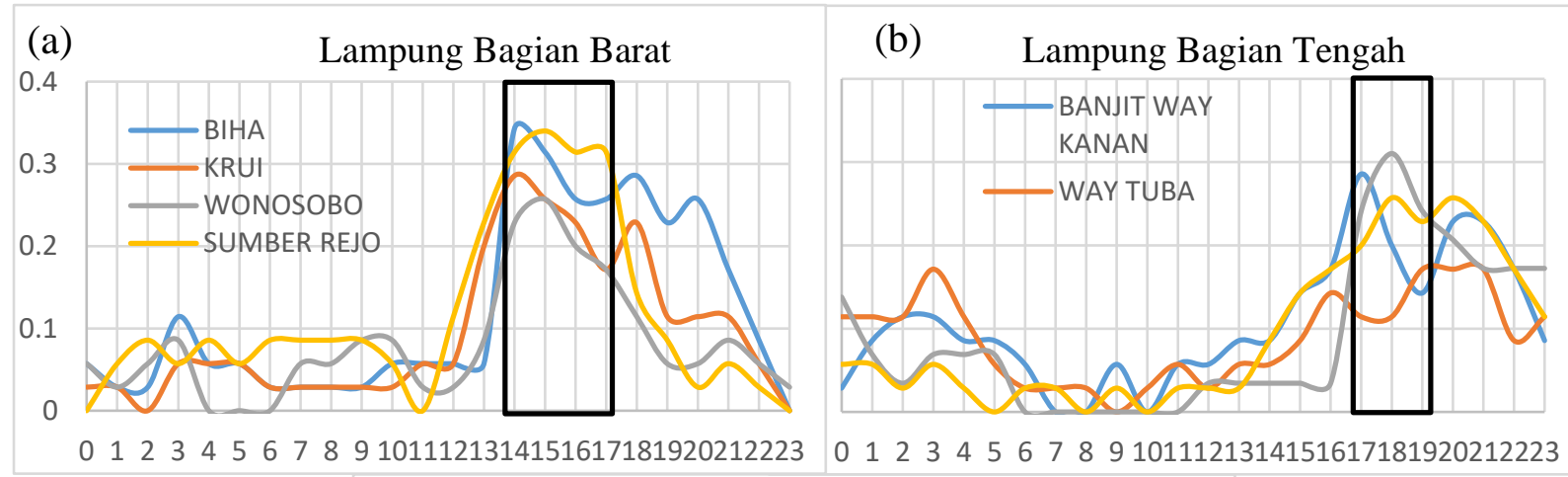

(c) Lampung Bagian Timur

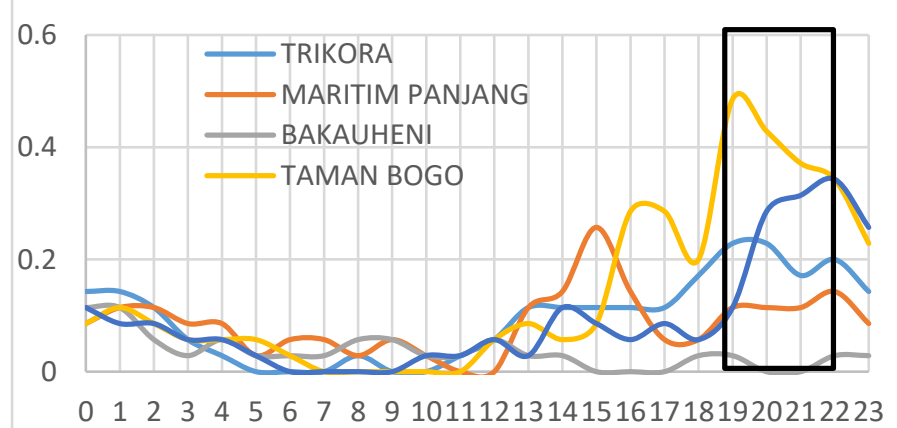

Gambar 11. Frekuensi kejadian hujan Fase 3 a) Lampung bagian barat; b) Lampung bagian tengah; c) Lampung bagian timur

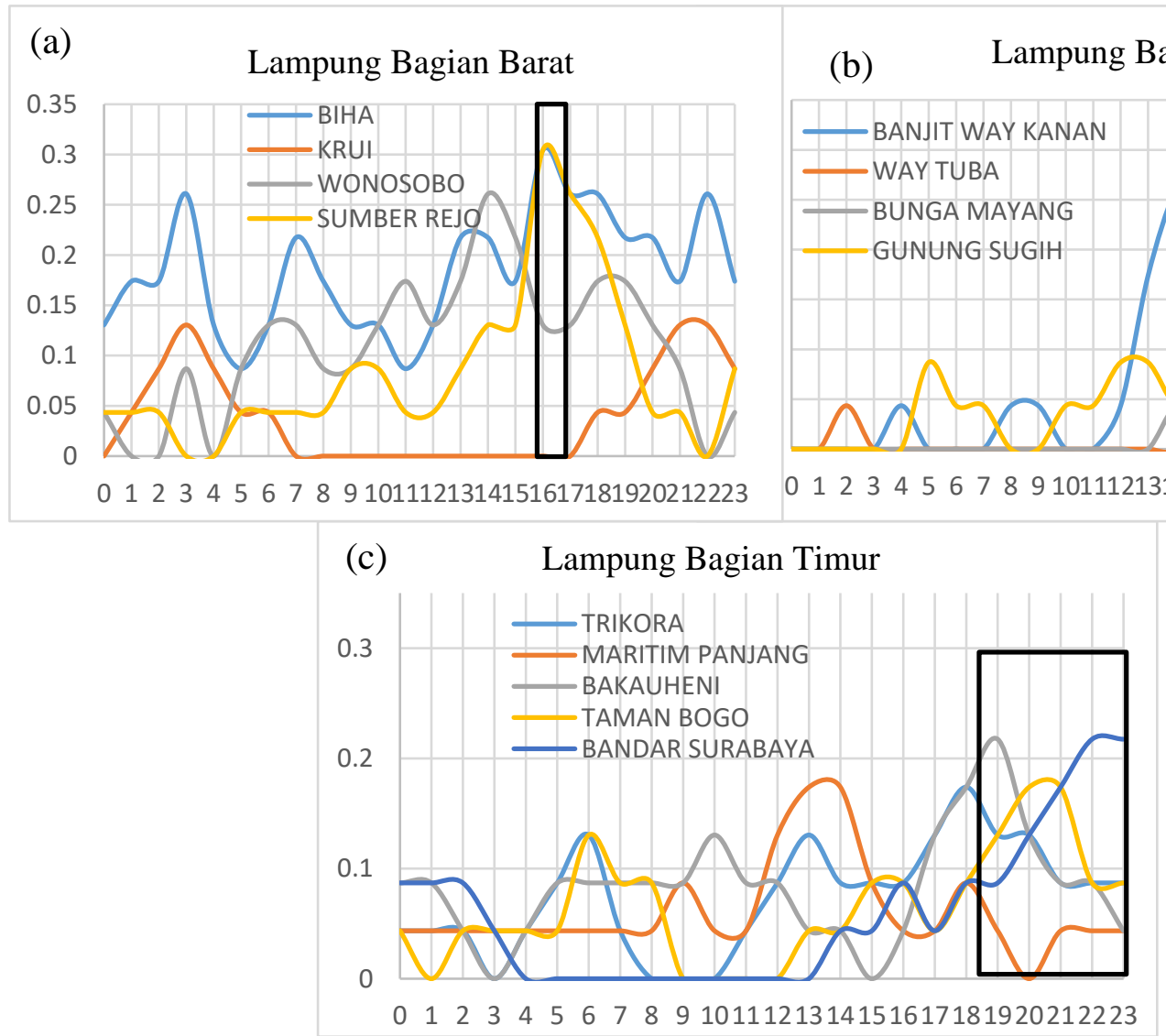

Gambar 12. Frekuensi kejadian hujan Fase 4 a) Lampung bagian barat; b) Lampung bagian tengah;

c) Lampung bagian timur 


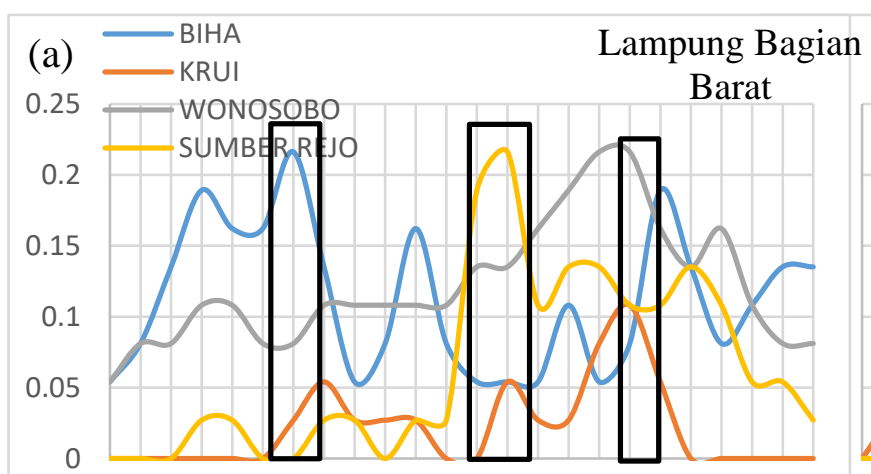

(b) Lampung Bagian Tengah

0123456789101112131415161718192021222301234567891011121314151617181920212223

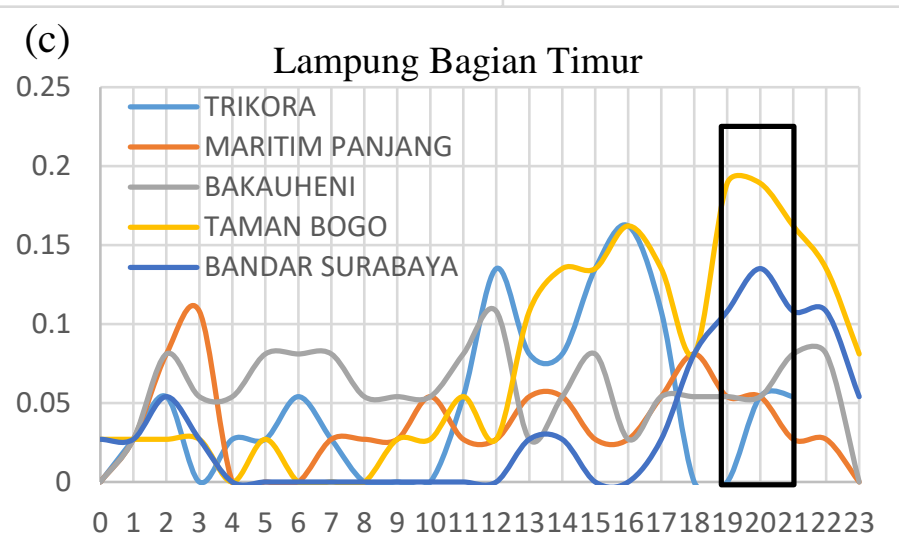

Gambar 13. Frekuensi kejadian hujan Fase 5 a) Lampung bagian barat; b) Lampung bagian tengah; c) Lampung bagian timur

Berdasarkan frekuensi kejadian hujan, ketika MJO Fase 3-5 maka hujan paling sering terjadi di wilayah lampung bagian barat hingga tengah daripada Lampung bagian timur. Hasil tersebut sesuai dengan penelitian Ariani (2014) yang menyatakan bahwa selama MJO aktif di wilayah Sumatera anomali curah hujan di wilayah barat Sumatera lebih besar daripada timur Sumatera. Menurut Wu dan Hsu (2009) hal tersebut dikarenakan adanya pengaruh dari topografi barat Sumatera yang merupakan dataran tinggi sehingga melemahkan sinyal penjalaran MJO di atas wilayah pegunungan yang menjalar dari perairan barat Sumatera.

Tabel 2. Puncak waktu terjadinya hujan di Lampung ketika MJO aktif

\begin{tabular}{|l|l|l|l|l|}
\hline & $\begin{array}{l}\text { Lampung } \\
\text { Barat }\end{array}$ & & $\begin{array}{l}\text { Lampung } \\
\text { Tengah }\end{array}$ & $\begin{array}{l}\text { Lampung } \\
\text { Timur }\end{array}$ \\
\hline $\begin{array}{l}\text { Fase } \\
3\end{array}$ & $14-16$ & & $16-19$ & $19-22$ \\
\hline $\begin{array}{l}\text { Fase } \\
4\end{array}$ & $16-17$ & & $20-21$ & $20-23$ \\
\hline $\begin{array}{l}\text { Fase } \\
5\end{array}$ & $\begin{array}{l}5-6, \quad 12- \\
13,17-18\end{array}$ & & $18-19$ & $19-21$ \\
\hline
\end{tabular}

Berdasarkan Tabel 2 kejadian hujan ketika MJO mempengaruhi wilayah Lampung (Fase 3-5) terjadi lebih cepat dengan durasi yang lebih lama. Menurut Oh et al. (2011) ketika Fase 1-4 maka akan terjadi penguatan angin diurnal di BMI bagian barat yang mengakibatkan proses konvergensi menjadi lebih cepat terbentuk daripada ketika MJO sudah tidak mempengaruhi wilayah Lampung. Selain itu, penjalaran MJO ke timur menyebabkan angin baratan bergerak lebih cepat sehingga dapat mempercepat penjalaran hujan menuju timur. Menurut Syafrijon (2013) ketika MJO aktif mempengaruhi suatu wilayah maka hujan terjadi ketika sore hingga malam hari dengan durasi hujan yang lebih lama. Ketika Fase 5 hujan rata-rata terjadi hampir pada semua waktu di Lampung bagian barat, kemudian Lampung bagian tengah pada pukul 18-19 LT dan Lampung bagian timur pada pukul 19-21 LT. Hujan terjadi lebih awal ketika berada di Lampung bagian barat yaitu pukul 14-16 LT pada Fase 3, kemudian pukul 14-17 LT pada Fase 4. Menurut Birch et al. (2016) yang menyatakan bahwa ketika MJO mempengaruhi wilayah BMI bagian barat (Fase 23) maka hujan mulai memasuki wilayah pesisir pada sore hari hingga malam hari (14-20 LT) kemudian meluas di daratan pada pukul 20-00 LT. Hal tersebut menandakan bahwa ketika MJO aktif di wilayah Lampung bagian tengah hujan terjadi 25 jam kemudian ketika Fase 3, 4-7 jam kemudian ketika Fase 4, dan 1-2 jam kemudian ketika Fase 5. Hal tersebut menandakan bahwa di wilayah Lampung bagian tengah Fase 5 tidak terlalu berpengaruh terhadap penjalaran hujan ke timur, sedangkan Fase 3 dan 4 mempengaruhi penjalaran hujan di Lampung bagian tengah. Di wilayah Lampung bagian timur ketika Fase 3 hingga Fase 5 tidak terdapat perbedaan waktu 
terjadinya hujan yang signifikan dengan waktu terjadinya hujan pada fase lainnya kecuali Fase 4 yang terjadi 1-2 jam lebih lambat daripada Fase lainnya. Hal tersebut menandakan bahwa MJO Fase 3-5 tidak begitu berpengaruh terhadap penjalaran hujan ke timur di wilayah Lampung bagian timur.

\section{KESIMPULAN}

Berdasarkan hasil penelitian dan pembahasan maka dapat disimpulkan bahwa konvektivitas kuat terjadi di perairan maupun daratan pada Fase 3 kemudian berkurang di perairan dan menyebar di daratan pada Fase 4 dengan intensitas yang lebih kecil. Penurunan konvektifitas terjadi pada Fase 5 baik di daratan maupun perairan.

Wilayah dengan curah hujan tinggi sesuai dengan wilayah konvektivitas kuat. Curah hujan tinggi terjadi di perairan maupun daratan pada Fase 3 kemudian berkurang di perairan dan menyebar di daratan pada Fase 4 dengan intensitas lebih kecil. Selain itu, curah hujan menurun pada Fase 5 baik di daratan maupun perairan.

Jika dilihat dari siklus diurnal di Lampung, hasil penelitian menunjukkan adanya konvektivitas yang kuat dan curah hujan tinggi terjadi di wilayah perairan pada pukul 00-06 LT dan 06-12 LT kemudian memasuki pesisir pada pukul 12-18 LT dan sampai di daratan pada pukul 18-00 LT. Siklus diurnal tersebut mengalami peningkatan dari Fase 3-4 dan melemah ketika Fase 5.

Hujan menjalar dari Lampung bagian barat menuju Lampung bagian tengah dengan perbedaan waktu 2-5 jam ketika Fase 3, 4-7 jam ketika Fase 4, dan 1-2 jam ketika Fase 5. Pada Fase 3-5 hujan terjadi di Lampung bagian timur dengan perbedaan waktu 1-3 jam dari Lampung bagian tengah.

\section{DAFTAR PUSTAKA}

Arbain, A. A., Renggono, F., \& Yahya, R. Y. (2017). Pengaruh Madden-Julian Oscillation Terhadap Distribusi Temporal Dan Propagasi Hujan Berdasarkan Pengamatan Radar Cuaca (Studi Kasus: Intensive Observation Period 2016 di Wilayah Jakarta dan Sekitarnya), Jurnal Sains \& Teknologi Modifikasi Cuaca, 18(2), pp.43-50. doi:10.29122/jstmcv18i2.2058.

Ariani, R. (2014). The Influence of the MaddenJulian Oscillation on Diurnal Cycle of Rainfall over Sumatera. Thesis. Fakultas Matematika dan IImu Pengetahuan Alam, Institut Pertanian Bogor, Bogor.

Birch, C. E., Webster, S., Peatman, S. C., Parker, D. J., Matthews, A. J., Li, Y., dan Hassim, M. E. E. (2016). Scale Interactions between the MJO and the Western Maritime Continent, Journal of Climate, 29(7), pp.2471-2492. doi:10.1175/JCLI-D-150557.1

Hermawan, E. (2010). Analisis Struktur Vertikal MJO Terkait dengan Aktivitas Super Cloud Cluster (SCCs) di Kawasan Barat Indonesia. Jurnal Sains Dirgantara, 8, pp.26-42.

Hermawan, E. (2011). Peran Data Indeks Monsun Global dan IOD Terhadap Perilaku Curah Hujan Di Beberapa Kawasan Indonesia, Prosiding Seminar Nasional Sains Atmosfer dan Antariksa, Bandung.

Hidayat, R., Kizu, S. (2009). Influence of the Madden-Julian Oscillation on Indonesia Rainfall Variability in Austral Summer, International Journal of Climatology, 30, pp.1816-1825. doi:10.1002/joc.2005.

Higgins, R. W. dan Shi, W. (2001). Intercomparison of the principal modes of interannual and intraseasonal variability of the North American Monsoon System, Journal of Climate. American Meteorological Society, 14, pp.403-417.

Lu, J., Li, T., dan Wang, L. (2019). Precipitation Diurnal Cycle over the Maritime Continent Modulated by the MJO, Climate Dynamics, 53, pp.6489-6501.

Madden, R. A, dan Julian, P. (1971). Detection of a 40-50 Day Oscillation in the Zonal Wind in the Tropical Pacific, Journal of The Atmospheric Sciences, 28, pp.702-708. doi:10.1175/15200469(1971)028<0702:DOADOI>2.0.CO;2

Madden, R. A., \& Julian, P. R. (1972). Description of global-scale circulation cells in the tropics with a 40-50 days period, Journal of The Atmospheri Science, 29, hal:1109-1123.

Madden, R. A., \& Julian, P. R. (1994). Observations of the 40-50 Day Tropical Oscillation: A review, Mon. Weather Rev, 112, pp.814 - 837 .

Nesbitt, S. W., dan Zipser, E. J. (2003). The Diurnal Cycle of Rainfall and Convective Intensity according to Three Years of TRMM Measurements, Journal of Climate, 16(10), pp.1456-1475.

Oh, J. H., Kim, K. Y., dan Lim, G. H. (2011), Impact of MJO on The Diurnal Cycle of Rainfall over The Western Maritime Continent in The Austral Summer, Climate Dynamics, Vol.38, pp.1167-1180.

Peatman, S. C., Matthews, A. J., dan Stevens, D. P. (2014). Propagation of the MaddenJulian Oscillation through the Maritime Continent and scale interaction with the diurnal cycle of precipitation, Quarterly Journal of the Royal Meteorological Society, 140, pp.814-825.

Syafrijon. (2013). Pengaruh MJO Terhadap Perilaku Hujan Harian di Atas Kototabang, 
84 Pengaruh Propagasi Madden Julian Oscillation... (Sindy Maharani \& Hasti Amrih Rejeki)

Prosiding Seminar Nasional Sains Atmosfer dan Antariksa, Bandung.

Wirjohamidjojo, S., \& Swarinoto, Y. (2010). Iklim Kawasan Indonesia: Dari Aspek Dinamik Sinoptik, Badan Meteorologi Klimatologi dan Geofisika, Jakarta.

Wu, C.-H., \& Hsu, H.-H. (2009). Topographic Influence on the MJO in the Maritime Continent, Journal of Climate, 22(20), pp.5433-5448.

doi:10.1175/2009JCLI2825.1.
Zhang, C., dan Ling, J. (2017). Barrier Effect of the Indo-Pacific Maritime Continent on the MJO: Perspectives from Tracking MJO Precipitation. Journal of Climate, 30(9), pp. 3439-3459. doi:10.1175/JCLI-D-160614.1.

Zhang, L., Wang, B., dan Zeng, Q. (2009). Impact of the Madden-Julian Oscillation on Summer Rainfall in Southeast China, Journal of Climate. American Meteorological Society, 22, pp.201-216. doi:10.1175/2008JCLI1959.1. 